\title{
Background Research and Field Monitoring of Riverwalk Stalls, Downtown San Antonio, Texas
}

I. Waynne Cox

Center for Archaeological Research

Follow this and additional works at: https://scholarworks.sfasu.edu/ita

Part of the American Material Culture Commons, Archaeological Anthropology Commons, Environmental Studies Commons, Other American Studies Commons, Other Arts and Humanities Commons, Other History of Art, Architecture, and Archaeology Commons, and the United States History Commons

Tell us how this article helped you.

This Article is brought to you for free and open access by the Center for Regional Heritage Research at SFA ScholarWorks. It has been accepted for inclusion in Index of Texas Archaeology: Open Access Gray Literature from the Lone Star State by an authorized editor of SFA ScholarWorks. For more information, please contact cdsscholarworks@sfasu.edu. 


\section{Background Research and Field Monitoring of Riverwalk Stalls, Downtown San}

Antonio, Texas

\section{Creative Commons License}

\section{(c) (1) \&}

This work is licensed under a Creative Commons Attribution-NonCommercial 4.0 International License 
BACKGROUND RESEARCH AND FIELD MONITORING OF RIVERWALK STALLS, DOWNTOWN SAN ANTONIO, TEXAS

I. Waynne Cox

Center for Archaeological Research The University of Texas at San Antonio Archaeological Survey Report No. 201 1990 



\begin{abstract}
During the latter part of 1986, the Center for Archaeological Research, The University of Texas at San Antonio, monitored the construction of a set of Riverwalk stalls constructed in a section of the Riverwalk north of Commerce Street between St. Mary's and Navarro Streets. Excavation was mostly in river bank fill deposited during the construction of the Riverwalk under the Works Project Administration. During excavations, a well was encountered and a part of it was disturbed. A sample of artifacts from the well fill indicated that it was associated with the Nette Drug Store and dated between ca. 1870 to 1900. In order to preserve the contents, the well was covered and protected.
\end{abstract}




\section{TABLE OF CONTENTS}

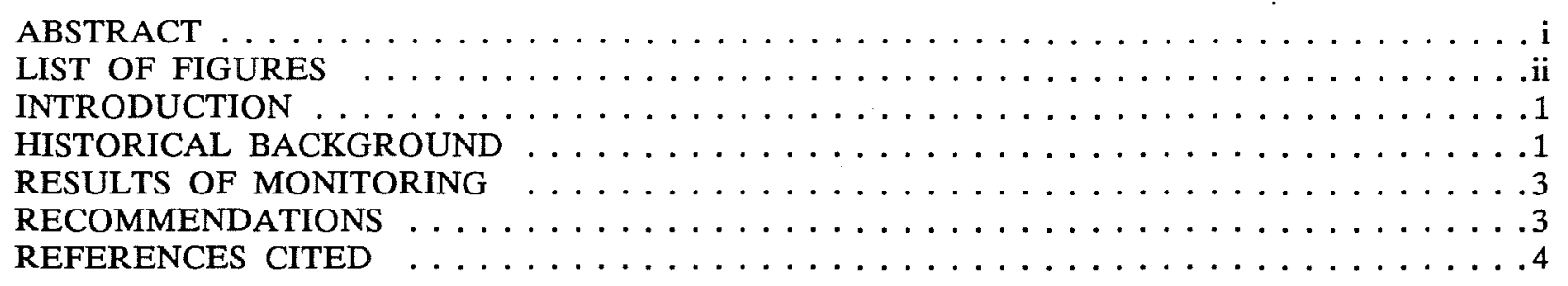

\section{LIST OF FIGURES}

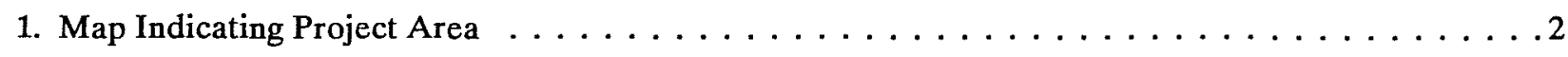




\section{INTRODUCTION}

In September of 1986, the Center for Archaeological Research, The University of Texas at San Antonio, entered into a contract with the Department of Downtown Initiatives to conduct archival research and excavation monitoring of the construction of commercial wall stalls along the Riverwalk in downtown San Antonio, Texas. The area of concern was located on the river between New City Blocks (NCB) 116 and 405. Construction and monitoring began in late 1986 and continued into the early part of 1987 (Fig. 1).

The area in question is located on the San Antonio Riverwalk between St. Mary's and Navarro Streets in downtown San Antonio, Texas. The NCB on the north side of the river is designated NCB 405, and on the south as NCB 116. NCB 405 is presently occupied by St. Mary's Church and La Mansion del Rio Hotel, and NCB 116 contains Crockett Street along the south bank of the river. The construction consisted of excavation of a landscaped area in the river bank, fabrication of a new retaining wall, and excavation of the sidewalk area on the north side of Crockett Street. The excavation was dug to a depth of approximately 15 feet below the bank top for the construction of the river stalls that had been designed in the Riverwalk's master plan.

\section{HISTORICAL BACKGROUND}

The property on both banks of the river was a portion of the land granted to Ambrosio Rodriguez. Rodriguez, the grandson of one of the original Canary Islanders, served as a Lieutenant under Colonel Juan Seguin in Houston's army at the battle of San Jacinto (Chabot 1937:171). As stated by his son, José Maria:

“... We owned all the property on both sides of the river clear to Convent Bend (Convent Street), including Houston Street and what is now the Gunter Building and the Gunter Hotel, all planted in a corn field and other crops" (Rodriguez 1913:35).

After the death of Ambrosio, in 1848, the property passed to his heirs and a large portion was disposed of to provide educations for his eight children (Webb 1952 Vol. II:497; Rodriguez 1913:48).

The property on the north bank of the river (NCB 405) was purchased from the heirs by John Twohig and José Cassiano(BCDR I1:466). Twohig's residence was on the west side of St. Mary's Street and his bank just to the west on Commerce Street (City Directory 1879-80). Twohig sold his portion of the property to James Henderson in 1851 (BCDR K1:84). Cassiano and Henderson conveyed the property to Bishop John M. Odin in July of 1852 (BCDR K2:158,159). The Bishop, in turn, passed the property to Father Claude M. Dubuis as the site of the second parish church to serve the English-speaking Catholics of the city. The cornerstone for St. Mary's Church was laid on January 15, 1858 (Furey 1974:79). The church was in continuous use until the flood of 1921 , when the building sustained $\$ 100,000$ in damages and was rendered unsafe due to structural weakness. The first church was razed in 1923. The cornerstone for the new church was laid January 13, 1924, and the church remains in use today (Steinfeldt 1978:135).

The remaining land purchased by Bishop Odin was conveyed to the Society of Mary, or Marianist, a religious organization of men devoted to teaching. Construction on the rectangular two-story structure, 60 feet long and 25 feet wide, was begun in the fall of 1852, and existed as St. Mary's College until the University moved in 1929. The College Street location continued as the downtown campus until the 1950's (Schmitz 1951:29,30,77).

The property on the south bank of the river (NCB 116) was initially purchased from Rodriguez by Pedro Salinas on June 12,1820, who later divided the property into small lots and resold them during the 1840's, primarily for residential occupation. Among these residents were Louisa Laso de Dimitt (widow of Phillip Dimitt, hero of the Texas War of Independence), Margarita Herrera de Seguin, Antonio Baca and Micaela Farragosa (BCDR A2:495). Farragosa conveyed her property (Lots 2-5) to Wilson Irvine Riddle (BCDR A2:375). Riddle arrived in Texas in 1839 and married Elizabeth Mary Menfree of Virginia in 1841. They came to San Antonio on May 22, 1841, and had their home constructed on the Commerce Street property. Their daughter, Sarah, was born there on February 19, 1842. Riddle was captured in 1842 by General Woll and imprisoned in Perote Prison in Mexico. As a result of illness contracted during his captivity, he died in 


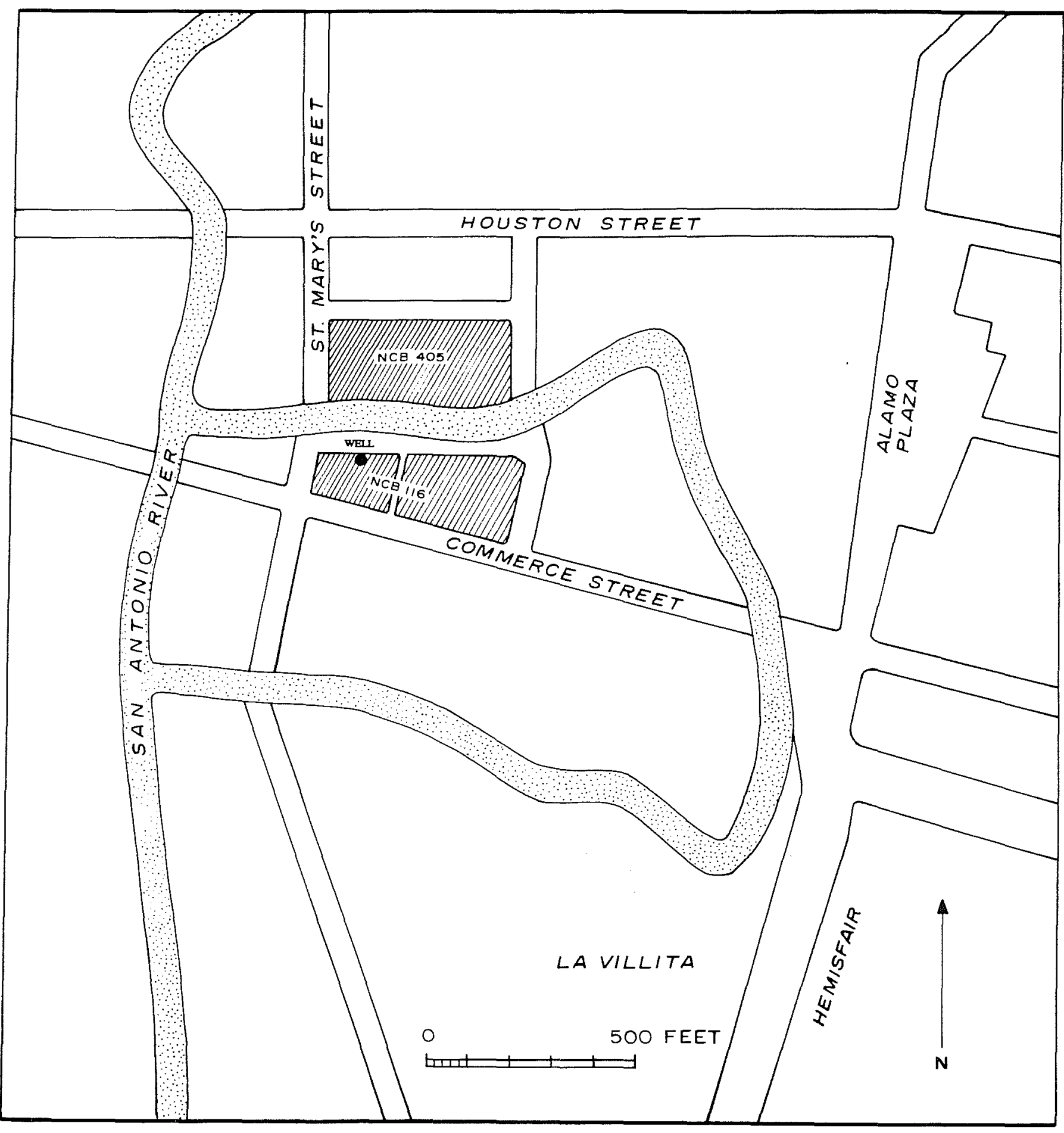

Fig 1. Map Indicating Project Area 
San Antonio on March 12, 1847. His widow, Elizabeth, remarried on May 8, 1851 to Harvey Canterbury. Sarah Riddle married Robert Eager in 1866 (Corner 1890:107-8). The property, along with other holdings, was divided equally between Elizabeth Canterbury and Sarah Eager.

The property to the east (Lots 6 and 7) was purchased by August Nette. Nette arrived in Texas in 1845, and joined Dr. Julius Heusinger in the apothecary and drug business in May of 1850 . Nette purchased the business five months later. His drug store occupied the property for a number of years. The area was soon all commercial businesses (Steinfeldt 1978:156).

In December of 1889 , the majority of the citizens agreed to grant the city right-of-way along the river, from Losoya Street to St. Mary's Street, to be opened and named Crockett Street. The city agreed to grade and drain the street, build a river retaining wall, and to bridge the river (San Antonio Express, December 17, 1889).

In June of 1926, the Aztec Theater was opened with great pomp and ceremony. It was constructed on NCB 116, Lots 2-9, by William Epstein. The architect was the noted Robert B. Kelly and the stage curtain designed by Herbert Bernard (SACS 1978:9).

In 1938, the Works Projects Administration (WPA) contributed $\$ 355,000$ toward the beautification of the San Antonio River from Jefferson Street to La Villita, with the additional cost to be obtained from the property owners at an assessment of $11 / 2$ cents per $\$ 100$ valuation. Robert Harvey Hugman was selected as the architect. The work, now called the Riverwalk, was completed March 14, 1941. Among the project envisioned but not completed was a group of shops in stalls on the south side of the river at St. Mary's Street near the bridge.

In 1966, the city undertook the alteration of Crockett Street by eliminating the north lane of traffic and expanding the sidewalk from eight feet to sixteen feet (San Antonio Express, March 18, 1966). In 1978, Crockett Street was beautified by the addition of brick walkways and newly designed street lights (San Antonio Express, September 18, 1979).

\section{RESULTS OF MONITORING}

Construction on the Riverwalk Stalls began in December of 1986. By the end of the year the trees and sidewalks had been removed, the river bank had been cut back and stonework had begun. By mid January 1987, the river bank had been excavated to a depth of approximately ten feet and revealed only recent fill deposited during the WPA construction of a retaining wall. The UTSA archaeologist monitoring the construction was notified that the final excavation of the south wall had intruded into a stone lined structure on the northern portion of Lots 6 and 7 of NCB 116.

Upon examination, the structure appeared to be a stone lined well at the rear of what had been the Nette Drug store. Only a section of the north wall of the well had been removed with the contents exposed in the south profile. They consisted of an assortment of patent medicine and apothecary bottles dating from the period of 1870 to 1890 . The well seems to have been capped and sealed no later than the opening of Crockett street in 1889 to 1890 . A selected sample of the contents were removed and are curated at the CAR-UTSA. The construction crew was instructed to cover the well and avoid further impact of the structure.

\section{RECOMMENDATIONS}

Since the well structure was not substantially disturbed by the excavations and was not to be further impacted, it was determined that excavation of the contents was not essential. The well was covered and sealed by the construction of the stalls, thus protecting and preserving the contents. If, in the future, additional construction be contemplated at the river stalls that would affect the well, a full excavation of the well to remove its contents and document the construction should be considered. 


\section{REFERENCES CITED}

Bexar County

Bexar County Deed Records (BCDR)

County Clerk's Office, San Antonio.

Chabot, Frederick C.

1937 With the Makers of San Antonio. Privately published, San Antonio

City Directory

1879-80 Directory of San Antonio, microfilm CAR-UTSA, San Antonio.

Corner, William

1890 San Antonio de Bexar: A Guide and History. Bainbridge and Corner, San Antonio.

Furey, F. J.

1974 Archdiocese of San Antonio 1874-1974. Francis J. Furey, Archbishop, San Antonio.

Rodriguez, José Maria

1913 The Rodriguez Memoirs of Early Texas. Passing Show Publishing Company, San Antonio.

San Antonio Conservation Society (SACS)

1978 The Newsletter, September, Vol. 15, No.10, San Antonio.

San Antonio Express

1889 The City Council, December 17, San Antonio.

1966 Crockett Street Changes, March 18, San Antonio.

1979 Beautification of Crockett Street, September 18, San Antonio.

Schmitz, J. W.

1951 The Society of Mary in Texas. Naylor Company, San Antonio.

Steinfeldt, C.

1978 San Antonio Was: Seen Through a Magic Lantern. Views from the Slide Collection of Albert Steves, Sr. San Antonio Museum Association, San Antonio.

Webb, W. P. (Editor)

1952 The Handbook of Texas. Two Volumes. Texas State Historical Association, Austin. 